\title{
Fjölmiðlar og heilbrigðiskerfið
}

Málefni heilbrigðiskerfisins eru oft til umfjöllunar í fjölmiðlum enda er um að ræða stóran og mikilvægan málaflokk sem snertir líf allra landsmanna einhvern tímann á lífsleiðinni. Heilbrigðiskerfið er dýrasti og sennilega flóknasti hluti okkar samfélags og á fáum sviðum hafa orðið eins miklar framfarir og breytingar á undanförnum árum. Öll viljum við geta gengið að pví vísu að pjónustan sé góð og að hún sé örugg og aðgengileg öllum sem á henni purfa að halda. En að sjálfsögðu er ekkert fullkomið í pessum heimi. Pví miður er fjölmiðlaumræða um heilbrigðismál oft á afar neikvæðum nótum og orð eins og úrræðaleysi, niðurskurður, mannekla og fjársvelti eru algeng.

Fréttir af sumarlokunum, kjaradeilum, biðlistum og miklu álagi á heilbrigðisstarfsfólk eru nánast daglega á síðum fjölmiðla. Petta eru að sjálfsögðu afar erfið mál og raunverulegar áskoranir sem kerfið stendur frammi fyrir og mikilvægt er að fjalla um pau með gagnrýnum hætti í fjölmiðlum en pað skiptir líka máli hvernig pað er gert. Рað er afar mikilvægt að umfjöllun fjölmiðla um pennan málaflokk sé yfirveguð, byggð á staðreyndum og að reynt sé að forðast gífuryrði og upphrópanir.

Раð gerist reglulega að á síður fjölmiðla rata umfjallanir um erfið mál einstakra sjúklinga. Nú á tímum netmiðla geta einstaklingar með einföldum hætti deilt persónulegum reynslusögum sínum á netinu. Stundum er um að ræða lýsingar sjúklinga eða aðstandenda peirra á samskiptum sínum við heilbrigðisstarfsfólk par sem kvartað er yfir pví að viðkomandi hafi ekki fengið viðhlítandi pjónustu eða verið neitað um pjónustu. Jafnframt eru oft dregnar pær ályktanir að slíkar lýsingar á högum einstaklinga lýsi kerfinu eða pjónustunni í heild.

Af og til gerist pað líka að ákveðnir fjölmiðlar birta svona lýsingar á síðum sínum og skrifa með peim frétt. Í slíkum fréttum koma aðeins fram lýsingar og sjónarmið peirra sem telja að með einhverjum hætti hafi verið brotið á rétti peirra. Öllum fréttamönnum á að vera vel kunnugt um að á heilbrigðisstarfsfólki hvílir afar ströng pagnarskylda og trúnaður sem gerir peim ókleift að tjá sig um mál einstakra sjúklinga. Heilbrigðisstarfsmenn geta pví ekki brugðist við ef peir telja að hallað sé réttu máli eða аð mikilvægar upplýsingar vanti í umfjöllunina. Ekki parf að hafa mörg orð um pað hversu viðkvæm og flókin mál sem pessi geta verið. Рað er mikill ábyrgðarhluti að taka fyrir mál einstakra sjúklinga í fjölmiðlum.

Alltaf er hætta á pví að dregnar séu rangar ályktanir af pví sem á að hafa gerst og hætt er við pví að fréttir sem pessar ýti undir ótta og tortryggni hjá fólki sem parf að sækja pjónustu heilbrigðiskerfisins. Fréttaflutningur af pessu tagi er einnig líklegur til að valda heilbrigðisstarfsfólki miklu hugarangri og vanlíðan, sérstaklega ef pað parf að sitja undir óvæginni gagnrýni í fjölmiðlum og getur ekki komið fram og tjáð sig um sína hlið á málinu.

Раð er að sjálfsögðu afar mikilvægt að sjúklingar og aðstandendur peirra geti á skilvirkan og einfaldan hátt komið kvörtunum sínum á framfæri við pá sem stýra pjónustunni og bera ábyrgð á að gæði hennar séu tryggð. Síður fjölmiðla eru ekki rétti vettvangurinn til að ræða eða útkljá mál sem pessi enda slíkt ekki hægt pegar aðeins önnur hlið málsins er rædd. Alltaf er hætt við að umræðan verði mjög tilfinningahlaðin og einkennist af upphrópunum og gífuryrðum.

Æskilegt væri að ritstjórar og ábyrgðarmenn helstu fjölmiðla landsins settust niður með forsvarsmönnum heilbrigðiskerfisins og ræddu hreinskilnislega um hvernig best sé að fjalla með ábyrgum og yfirveguðum hætti um heilbrigðismál, pjónustunni til framdráttar, og hvernig koma megi í veg fyrir að lýsingar sem oft eru settar fram í mikilli reiði og geðshræringu séu gerðar að fréttaefni í fjölmiðlum.

Einnig er mikilvægt að heilbrigðisstarfsmenn sem eru aðilar að málum sem rata í fjölmiðla hafi vettvang innan kerfisins til pess að ræða málið og geti jafnframt fengið viðeigandi stuðning pegar peir sitja undir alvarlegum ásökunum í fjölmiðlum.

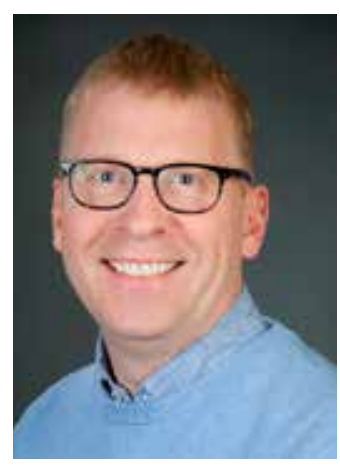

\section{Magnús Haraldsson}

geðlæknir við Landspítala, dósent við læknadeild Háskóla Íslands og situr í ritstjórn Læknablaðsins

hmagnus@landspitali.is

\section{Media and the health care system}

Magnús Haraldsson MD, PhD, Psychiatrist, Psychosis Outpatient Clinic, Division of Mental Health, Landspítali, University Hospital, associate professor University of Iceland

doi.org/10.17992//bl.2018.11.201 